\title{
Study of the inhibitory effects of chrysin and its nanoparticles on mitochondrial complex II subunit activities in normal mouse liver and human fibroblasts
}

\author{
Eman M. Ragab, Doaa M. El Gamal, Tarek M. Mohamed and Abeer A. Khamis * (1)
}

\begin{abstract}
Background: Mitochondrial complex II has a unique biological role owing to its participation in both the citric acid cycle and the electron transport chain. Our goal was to evaluate the succinate dehydrogenase and ubiquinone oxidoreductase activity of mitochondrial complex II in the presence of chrysin and chrysin-chitosan nanoparticles. Chrysin chitosan nanoparticles were synthesized and characterized using ultraviolet spectroscopy, Fourier transforminfrared spectroscopy, X-ray diffraction, transmission electron microscopy, scanning electron microscopy, drug release, and zeta potential. The binding affinity of chrysin to complex II subunits was assessed by molecular docking. The $I C_{50}$ values were measured in a suspension of mouse mitochondria, and the inhibitory effect of chrysin and chrysin chitosan nanoparticles on mitochondrial complex II was determined.
\end{abstract}

Results: The free energy of binding between chrysin and complex II subunits A, B, C, and D was $-4.9,-5,-8.2$, and $-8.4 \mathrm{kcal} / \mathrm{mol}$, respectively. The characteristic peak of chrysin was confirmed at $348 \mathrm{~nm}$. The chrysin chitosan nanoparticles contained characteristic bands of both chrysin and chitosan. The crystalline nature of chrysin chitosan nanoparticles was confirmed by $X$-ray powder diffraction measurements showing the characteristic Bragg peaks of $\left(11.2^{\circ}\right)$, $\left(32.2^{\circ}\right),\left(19.6^{\circ}\right),\left(27.6^{\circ}\right)$, and $\left(31.96^{\circ}\right)$. Transmission and scanning electron microscopy revealed their spherical shape and an average particle size of $49.7 \pm 3.02 \mathrm{~nm}$. Chrysin chitosan nanoparticles showed a burst release within the initial $2 \mathrm{~h}$ followed by a steady release at $8 \mathrm{~h}$. Their zeta potential was positive, between $+35.5 \mathrm{and}+80 \mathrm{mV}$. The $\mathrm{IC}_{50}$ of chrysin, chitosan nanoparticles, chrysin chitosan nanoparticles, and 5-fluorouracil was 34.66, 184.1, 12.2, and $0.05 \mu \mathrm{g} / \mathrm{mL}$, respectively, in adult mice liver and 129,311,156, and $8.07 \mu \mathrm{g} / \mathrm{mL}$, respectively, in normal human fibroblasts. When comparing the inhibitory effects on complex II activity, application of the $I C_{50}$ of chrysin, chitosan nanoparticles, chrysin chitosan nanoparticles, and 5-fluorouracil resulted in 40.14\%, 90.9\%, 86.7\%, and 89\% decreases in SDH activity and $70.09 \%, 86.74 \%, 60.8 \%$, and $80.23 \%$ decreases in ubiquinone oxidoreductase activity in normal adult mice, but $80.9 \%, 89.06 \%$, and $90 \%$ significant decreases in SDH activity, and 90\%, 85\%, and 95\% decreases in ubiquinone reductase after treatment with chrysin, chrysin chitosan nanoparticles, and 5-fluorouracil, in normal human fibroblasts, respectively.

Conclusions: Chrysin and CCNPs exhibit potent inhibitory effects on SDH activity ubiquinone oxidoreductase activity.

Keywords: Succinate dehydrogenase, Chrysin, Chitosan, Nanoparticles, Mitochondria, Complex II

*Correspondence: abeer.khamis@science.tanta.edu.eg

Biochemistry Division, Chemistry Department, Faculty of Science, Tanta University, Tanta 31527, Egypt 


\section{Background}

Mitochondria are organelles known for their function in cellular respiration, specifically for connecting molecular oxygen $\left(\mathrm{O}_{2}\right)$ reduction to ATP synthesis [1]. The electron transport chain (ETC) in mitochondria regulates the key metabolic pathway of oxidative phosphorylation (OXPHOS), which is one of mechanisms of energy homeostasis mechanisms [2]. OXPHOS is defined as the metabolic activity by which cells convert energy in the inner membrane of mitochondria via five functional enzymatic complexes-complex I (NADH: ubiquinone oxidoreductase), complex II (succinate: ubiquinone oxidoreductase), complex III (ubiquinol: cytochrome c oxidoreductase), complex IV (cytochrome c oxidase), and complex V (ATP synthase)-to oxidize nutrients, eventually creating molecular oxygen and releasing ATP [3]. OXPHOS begins with the entrance of electrons into complex I of the respiratory chain, which are subsequently passed to the following complex by sequential transfer, eventually resulting in ATP creation [4].

Succinate dehydrogenase (SDH), also known as mitochondrial complex II, is a mitochondrial enzyme that participates in both the citric acid cycle and the ETC, oxidizing succinate to fumarate and reducing ubiquinone to ubiquinol [5]. SDHA, SDHB, SDHC, SDHD, SDHAF1, and SDHAF2 are the six subunits that form SDH, the last two of these code for associated accessory factors [6]. SDH has previously been directed to the ubiquinone binding site to inhibit the ETC and production of ATP and ROS, as well as to induce apoptosis.

Natural components found in food and medicinal plants are considered an important resource for the discovery of new and important therapeutic molecules. Biomolecules are highly diverse, with potent antioxidant, anti-inflammatory, and anticancer properties. As shown by quantitative structure-activity relationship studies, biomolecules can be used as templates for chemical modifications to improve the efficiency, safety, and bioavailability of compounds [7]. Chrysin is a naturally occurring flavone that is abundant in various plant extracts, including propolis and honey [8]; it has emerged as an outstanding health-beneficial compound owing to its anti-inflammatory, antioxidant, antidiabetic, antiallergic, antibacterial, antiestrogenic, and anticancer capabilities [9].

Given the rapid growth of technology, it appears that there are no limitations to the possibilities through which nanotechnology can be used to serve and advance the human race. Nanotechnology is a rapidly developing field of technology worldwide that has caught the attention of both scientists and clinicians. Nanoparticles (NPs) are typically used for a wide range of applications. Most of those applications make use of the high surface area to mass ratio of NPs, which provides a large functional surface for the binding, adsorption, and carrying of other compounds [10].

We used molecular docking to investigate the binding affinity of chrysin with SDH and revealed its binding characteristics. We encapsulated chrysin within the natural polymer chitosan, which exhibits adhesiveness, biocompatibility, and biodegradability, and is widely used for biological and biomedical applications. The positively charged chitosan molecule, which facilitates adherence to negatively charged cell membranes and enhances drug delivery, contributed to the improved stability of chrysin-chitosan nanoparticles (CCNPs) [11, 12]. This work aimed to study the effect of chrysin and CCNPs, compared that of with 5-fluorouracil, on the activity of mitochondrial complex II (succinate: ubiquinone oxidoreductase), both in theory using molecular docking and experimentally using normal adult mice and normal human fibroblasts.

\section{Methods \\ Chemicals}

Chrysin (>99\%), Tris $\mathrm{HCl}$, 5-fluorouracil (>99\%), and CS $\left(\mathrm{M}_{\mathrm{w}}=100-300 \mathrm{kDa}, 70-75 \%\right.$ deacylated $)$. Trisodium pentapolyphosphate (TPP, 99\%), Tween 80, and mitochondria isolation buffer (mannitol (>95\%), 4-(2-hydroxyethyl) piperazine-1-ethane sulfonic acid, $\mathrm{N}$-(2-hydroxyethyl), and piperazine- $\mathrm{N}$-(2-ethane sulfonic acid) [HEPES]), and MTT [3-(4,5-dimethylthiazol-2-yl)2,5-diphenyltetrazolium bromide]. All these chemicals were of analytical grade and purchased from SigmaAldrich Company in Germany. Dulbecco's modified Eagle's medium (DMEM) and fetal bovine serum (FBS) were purchased from (GIBCO, New York, USA). L-Glutamine, trypsin-EDTA, and trypan blue were purchased from Invitrogen (VIC, Australia). Penicillin/streptomycin was purchased from Thermo Fisher Scientific (Waltham, MA, USA).

\section{In silico studies}

The protein structure of SDH was retrieved and processed for in silico molecular docking investigations using the RCSB Protein Data Bank (PDB) (www.rcsb.org). The PDB contains data on three-dimensional structures of biomacromolecules. For SDH, a grid box was created around the co-crystallized ligand binding site [13]. The experimentation on molecular docking was performed using Docking Server 2009 and Discovery Studio Software Tools 2019 [14].

\section{Synthesis of chrysin chitosan nanoparticles (CCNPs)}

After pure chrysin powder was dissolved in $96 \%$ methanol, the solution was combined with $0.1 \% \mathrm{w} / \mathrm{v}$ chitosan 
solution in $0.1 \%$ acetic acid under magnetic stirring. Then, $40 \mathrm{~mL}$ TPP solution $(0.1 \% \mathrm{w} / \mathrm{v})$ and $1.075 \mathrm{~mL}$ Tween-80 solution $(0.01 \% \mathrm{v} / \mathrm{v})$ were added dropwise to the solution under magnetic stirring at $1000 \mathrm{rpm}$ to produce chrysin-loaded chitosan nanoparticles [15].

\section{Physical characterization of CCNPs}

The ultraviolet (UV) absorption of the supernatant of CCNPs subjected to ultracentrifugation was used to the measure encapsulation efficiency (EE) of chrysin. By analysis of the supernatants of standard chrysin solutions $(10-100 \mathrm{~g} / \mathrm{mL})$ in a UV/Vis spectrophotometer (Shimadzu, Japan), the relevant calibration curves were created. Measurements of chrysin were performed at 348 $\mathrm{nm}\left(\lambda_{\max }\right)[16]$.

The encapsulation efficiency (EE) of chrysin was calculated from the following formula:

$$
\mathrm{EE}(\%)=\left(\frac{\text { Amount of chrysin encapsulated in NPs }}{\text { Initial amount of chrysin used }}\right) \times 100
$$

All measurements were performed in triplicate and the results were reported as the mean \pm standard deviation [17].

\section{In vitro release study}

For the in vitro release study, CCNPs $(0.1 \mathrm{~g})$ were placed in $1 \times \mathrm{PBS}, \mathrm{pH}$ 7.4 $(50 \mathrm{~mL})$. The complete release system was maintained at $37^{\circ} \mathrm{C}$ under $100 \mathrm{rpm}$ continuous stirring. Every $2 \mathrm{~h}$ for $24 \mathrm{~h}, 1 \mathrm{~mL}$ of solution was removed and replaced with $1 \mathrm{~mL}$ of buffer [15]. The amount of loaded chrysin was analyzed by UV spectrophotometry. The amount of chrysin released from microspheres over a given time was determined via the following equation: Chrysin release $(\%)=$ amount of chrysin released from microspheres/total loading amount of chrysin in microspheres $\times 100[15]$.

\section{UV analysis}

A Shimadzu (UV-3101 PC) spectrometer attached to a shaking water bath (Julabo SW20C) was used to measure electronic absorption spectra of chrysin [18].

\section{Fourier transform infrared spectroscopy (FTIR) analysis}

The molecular bonding formation between chrysin and chitosan nanoparticles was studied using the infrared (IR) spectra recorded on $\mathrm{KBr}$ disks using a Perkin Elmer 1720 spectrophotometer in the range of $4000-400 \mathrm{~cm}^{-1}$. Pure chitosan nanoparticles and chitosan nanoparticles loaded with chrysin were measured [19].

\section{$X$-ray powder diffraction (XRD) spectroscopy}

A Philips X PERT-PRO X-ray diffractometer (GNR, APD2000PRO, Italy) equipped with a monochromatic $\mathrm{Cu} \mathrm{K}(1.5406 \mathrm{~A}) \mathrm{x}$-ray source was used to produce the XRD patterns of chitosan and CCNPs. The voltage employed was $45 \mathrm{kV}$ and the angle range was scanned from 5 to $35^{\circ}$ with a step size of $0.0167^{\circ}[20]$.

\section{Analysis of morphology and particle size of nanoparticles}

The morphological features of the CCNPs were investigated using a JEOL JEM-2100 high-resolution TEM operated at an accelerating voltage of $200 \mathrm{keV}$. Gatan Digital Micrograph software was used to view, collect, and interpret the TEM images. A dilute suspension of CCNPs in ethanol was dropped onto copper grids to prepare the samples for TEM examination [21, 22]. SEM was performed to determine the morphology, size, and shape of the surface of the particles (TESCAN VEGA $3 \mathrm{SBH}$ model). The sample was placed in an ion sputter on an electron microscope of a metal stub and coated in gold. A random scan of the stub was taken for the CCNPs [23].

\section{Determining zeta potential}

The electrophoretic mobility (UE) of CCNPs was measured using a folded capillary cell and the zeta potential $(\zeta)$ was measured using a Zetasizer Nano Series (Brookhaven, USA). For the experiment, $1 \mathrm{~mL}$ of diluted CCNPs was used. All measurements were performed in triplicate [24].

\section{Isolation of mitochondria from normal adult mice}

Five adult male Swiss albino mice, weighing 28-30 g, were purchased from the Faculty of Pharmacy, Alexandria University, Egypt. The mice were maintained under suitable temperature conditions and a 12-h light/dark cycle. The experimental animals were kept in accordance with the National Institute of Health's Guidelines for the Care and Use of Laboratory Animals. The experiments on animals were monitored by the Egyptian Ethical Committee of Tanta University's Faculty of Science (IACUC-SCITU-0165) [25]. At the end of the experimental period, the mice were euthanized by cervical dislocation after intraperitoneal (i.p.) administration of sodium pentobarbital anesthesia $(300 \mathrm{mg} / \mathrm{kg})$ [26]. The liver was removed from the peritoneal cavity. The gallbladder was then located and removed using a scalpel as previously described $[27,28]$.

\section{Determining $\mathrm{IC}_{50}$ of chrysin and CCNPs}

on succinate-ubiquinone oxidoreductase activity (complex II) in normal adult mice

The MTT technique was used to determine the activity of succinate dehydrogenase and to determine $\mathrm{IC}_{50}$ 
by examining the inhibitory effect of different concentrations of chrysin $(5-100 \mu \mathrm{M})$, CCNPs $(5-160 \mu \mathrm{M})$, CNPs $(200-2000 \mu \mathrm{g} / \mathrm{mL})$, and 5-fluorouracil (5-40 $\mu \mathrm{M})$ on the substrate of succinate $(400 \mathrm{mM})$, with rotenone $(40 \mathrm{mg} / \mathrm{mL})$, antimycin A $(2 \mathrm{mg} / \mathrm{mL})$, and $\mathrm{KCN}$ $(40 \mathrm{mM})$ added into the mitochondrial suspension (50 $\mu \mathrm{L})[29]$.

\section{Determination of protein content}

The mitochondrial protein content was detected using the Bradford assay [30].

Determining the effect of the $\mathrm{IC}_{50}$ values of chrysin, CCNPs, CNPs, and 5-fluorouracil on succinate dehydrogenase and coenzyme $Q$ reductase activities (complex II) Effect of $I C_{50}$ values of chrysin, CCNPs, 5-fluorouracil on SDH activity by the MTT test in normal adult mice

The MTT test was used to determine succinate dehydrogenase activity. Briefly, the mitochondrial suspension $(50 \mu \mathrm{L})$ was incubated with the $\mathrm{IC}_{50}$ concentrations of chrysin $(34.66 \mu \mathrm{g} / \mathrm{mL})$, CNPs $(184.1 \mu \mathrm{g} / \mathrm{mL})$, CCNPs $(12.2 \mu \mathrm{g} / \mathrm{mL})$, and 5 -fluorouracil $(0.05 \mu \mathrm{g} / \mathrm{mL})$ in normal cell lines; then, succinate $(400 \mathrm{mM})$ was added as a substrate and rotenone $(40 \mathrm{mg} / \mathrm{mL})$, antimycin $\mathrm{A}$ (2 $\mathrm{mg} / \mathrm{mL})$, and $\mathrm{KCN}(40 \mathrm{mM})$ were added as inhibitors of complex I, III, and IV of the ETC, respectively. The reaction volume was made up to $1 \mathrm{~mL}$ with 50 $\mathrm{mM}$ phosphate buffer and then incubated at $37^{\circ} \mathrm{C}$ for $30 \mathrm{~min}$. Then, $50 \mu \mathrm{L}$ of MTT $(0.025 \%)$ was added to the mitochondrial suspension. In the next step, $50 \mu \mathrm{L}$ of dimethyl sulfoxide (DMSO) was used to dissolve the formed formazan crystals. Finally, the absorbance at $570 \mathrm{~nm}$ was assayed using an ELISA reader (Tecan, Rainbow Thermo, Austria) [29].

\section{Determination of succinate dehydrogenase-coenzyme $Q$ oxidoreductase activity (CII)}

The mitochondrial suspension $(50 \mu \mathrm{L})$ obtained from normal adult mice was incubated with the $\mathrm{IC}_{50}$ values of chrysin, CNPs, CCNPs, and 5-fluorouracil, and the specific activity was detected as described in recent methods $[31,32]$. The activity of complex II was expressed as $\mathrm{nmol} / \mathrm{min} / \mathrm{mg}$ protein using the standard DCPI curve [33].

\section{In vitro cell viability studies using the MTT assay Cell culture}

Frozen human normal fibroblast cells (ATCCCRL-2524) were cultured in accordance with standard cell culture protocols. The cells were cultured in DMEM containing $4.5 \mathrm{~g} / \mathrm{L}$ glucose and $2 \% \mathrm{~L}$-glutamine and supplemented with $10 \%$ FBS and $1 \%$ penicillin-streptomycin solution. Initially, the cells were seeded at low density and maintained at $37^{\circ} \mathrm{C}$ in a $5 \%$ $\mathrm{CO}_{2}$ incubator with $95 \%$ humidity.

\section{Cell viability using MTT assay}

The MTT tests were used to assess cell proliferation (viability) in accordance with the method of Denizot and Lang [34]. The cells were counted and then reseeded in 96-well plates to a final concentration $1 \times$ $10^{5}$ cells $/ \mathrm{mL}\left(3 \times 10^{4}\right.$ cells/well $)$. The cells were treated with different concentrations of chrysin $(12.5-100 \mu \mathrm{M})$, CNPs $(500-2000 \mu \mathrm{g} / \mathrm{mL})$, CCNPs $(12.5-100 \mu \mathrm{M})$, and 5-fluorouracil as a parallel control (3.13-100 $\mu \mathrm{M})$. After $48 \mathrm{~h}$, the culture medium was removed and the cells were washed twice gently with ice-cold PBS, and 20 $\mu \mathrm{L}$ of MTT $(5 \mathrm{mg} / \mathrm{mL}$ ) was removed from the 96 -well microplates. The plates were placed in a cell culture incubator at $37^{\circ} \mathrm{C}$ for $4 \mathrm{~h}$. The microplates were then shaken at the highest speed for $20 \mathrm{~min}$ at room temperature; after the incubation, the medium/MTT was removed and added $100 \mu \mathrm{L}$ of DMSO was added to each well to dissolve the formazan produced. A negative control well, containing $10 \mu \mathrm{L}$ of MTT stock solution control added to $100 \mu \mathrm{L}$ of medium, was used. An ELISA reader was used to determine the absorbance of the plate at $570 \mathrm{~nm}$ (StatFax-2100, Awareness Technology, Inc., USA) [35].

The cell viability was determined as a percentage using the following equation:

$\%$ Viability $=$ Sample absorbance $/$ Control absorbance $\times 100$

$\mathrm{IC}_{50}=$ the concentration of chrysin, CCNPs, or 5-fluororacil that causes $50 \%$ inhibition of cell proliferation.

\section{Isolation of crude mitochondria from normal fibroblast cell lines}

To isolate mitochondria from cells, $4 \times 10^{6}$ normal fibroblasts were subjected to the protocol of Wieckowski et al. [36].

\section{Determination of the two activities of mitochondrial CII in normal fibroblast cell lines Determination of SDH activity by MTT test with IC 50 of chrysin, CCNPs, and 5-fluorouracil in normal cell lines}

The MTT test was used to evaluate succinate dehydrogenase activity. Briefly, mitochondrial suspension (50 $\mu \mathrm{L})$ was incubated with $\mathrm{IC}_{50}$ of chrysin $(129 \mu \mathrm{g} / \mathrm{mL})$, CCNPs $(156 \mu \mathrm{g} / \mathrm{mL})$, and 5-fluorouracil $(8.07 \mu \mathrm{g} / \mathrm{mL})$ in normal cell lines; then, succinate $(400 \mathrm{mM})$ was added as a substrate and rotenone $(40 \mathrm{mg} / \mathrm{mL})$, antimycin $A$ ( $2 \mathrm{mg} / \mathrm{mL})$, and $\mathrm{KCN}(40 \mathrm{mM})$ were added as inhibitors 
of complex I, III, and IV of the ETC, respectively. The reaction volume was made up to $1 \mathrm{~mL}$ with $50 \mathrm{mM}$ phosphate buffer, then incubated at $37^{\circ} \mathrm{C}$ for $30 \mathrm{~min}$. Then, $50 \mu \mathrm{L}$ of MTT $(0.025 \%)$ was added to the mitochondrial suspension. In the next step, $50 \mu \mathrm{L}$ of DMSO was used to dissolve the formed formazan crystals. Finally, the absorbance at $570 \mathrm{~nm}$ was assayed using an ELISA reader (Tecan, Rainbow Thermo, Austria) [29].

\section{Determination of succinate dehydrogenase-coenzyme $Q$ oxidoreductase activity (CII) in normal human cell lines}

The mitochondrial suspension $(50 \mu \mathrm{L})$ obtained from normal cell lines was incubated with the $\mathrm{IC}_{50}$ of chrysin $(129.1 \mu \mathrm{g} / \mathrm{mL})$, CCNPs $(1556 \mu \mathrm{g} / \mathrm{mL})$, and 5-fluorouracil $(8.07 \mu \mathrm{g} / \mathrm{mL})$. Specific activity was detected according to the method of Taylor et al. [31]. The calculated CII activity was expressed as $\mathrm{nmol} / \mathrm{min} / \mathrm{mg}$ protein using the standard DCPI curve [33].

\section{Statistical analysis}

The results are shown as the mean $\pm \operatorname{SEM}(n=3)$. GraphPad Prism, v.6, was used for all the statistical analyses. The tests were repeated three times and two-way ANOVA tests followed by post hoc Tukey tests were used to establish statistical significance. To assess SDH activity, we used ANOVA tests as a specialized statistical analysis test. The threshold for statistical significance was fixed at $P<0.05$.

\section{Results}

\section{In silico analysis}

Semi-empirical calculations yielded the optimal molecular structure of the inhibitor, which was used as an input file for the conformational search using a systematic search approach. We double-checked the known structures (PDB code: 1NEK, resolution 2.5) from the PDB. The natural ligand was removed from the active site and docked into the enzyme's binding site to characterize the binding pocket of the SDH-like protein (the grid dimensions were $x=60 \AA, y=30 \AA$, and $z=10 \AA$, with a grid spacing of $9 \AA$ ), as shown in Fig. 1 A. The square deviations between the predicted conformer and the observed X-ray crystallographic conformer, $0.3 \AA$, were clustered together (superimposition). The active site of SDH contained 25 amino acids: GLY 251, VAL 159, GLY 179, ALA 180, GLY 181, PRO 182, IIE 183, GLY184, THR 202, ASP 203, LEU 204, SER 205, ARG 208, IIE 223, CYS 249, THR 250, ALA 252, ALA

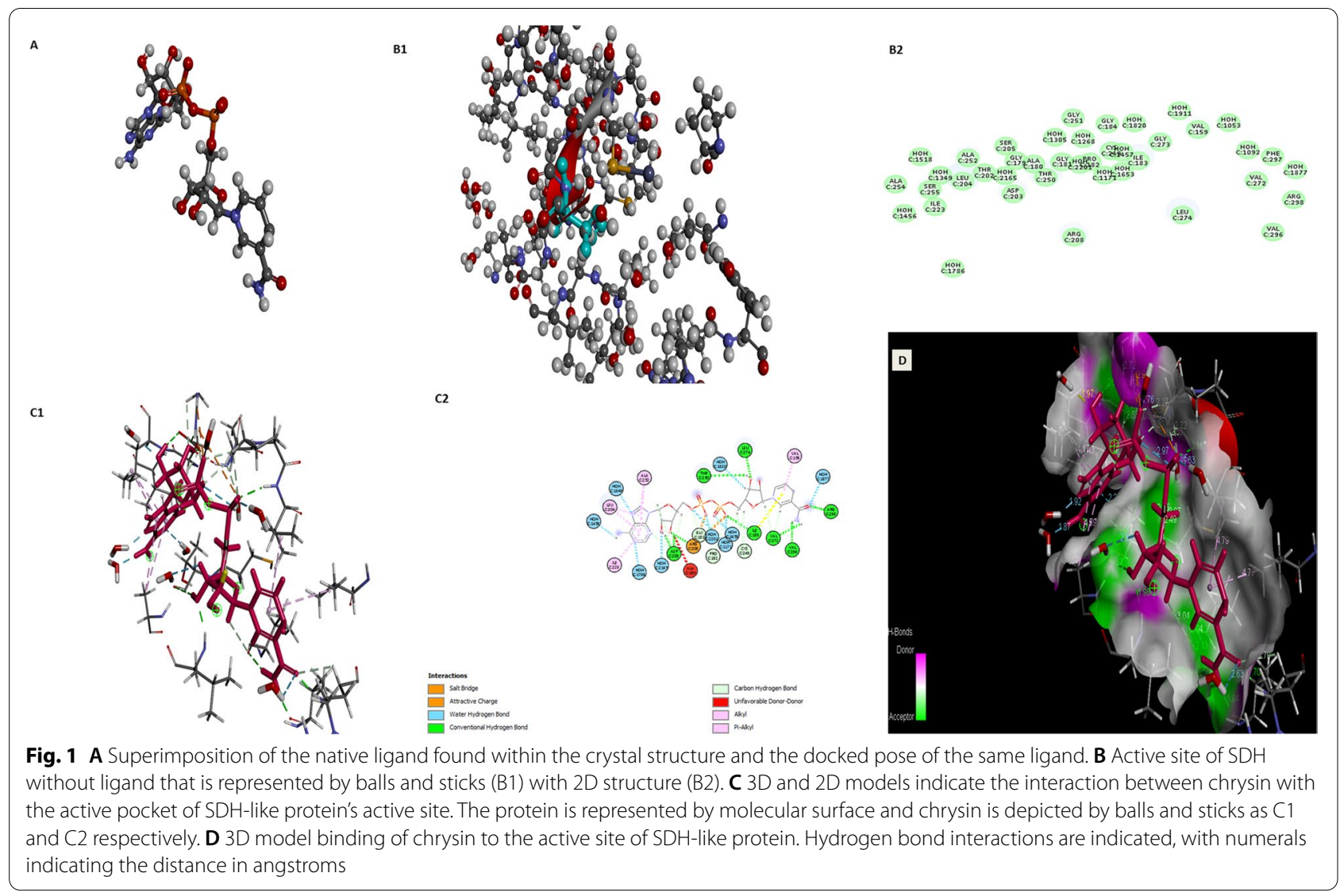


254, SER 255, VAL 272, GLY 273, LEU 274, VAL 296, PHE 297, and ARG 298 (Fig. 1B1, B2).

Docking analysis showed that the phenolic moiety and the $\mathrm{C}-\mathrm{H}$ group of chrysin were tightly bonded to the active site of SDH by several hydrogen bonds and van der Waals, hydrophobic, and electrostatic interactions. A possible conventional hydrogen bond between the (VAL272, VAL 296, ILE 183, ASP 203, ARG 298, THR 250, and LEU 274) and C-H (GLY 181, PRO 182, CYS 249) at the active site side-chain appeared to be responsible for the affinity of chrysin with SDH-like protein (Fig. 1C1, C2). The surface illustration of the minimum energy structure of the complex with chrysin docked in the active site of the SDH-like protein was determined from the molecular modeling study (Fig. 1D). The free binding energy was $-4.9,-5,-8.2$, and $-8.4 \mathrm{kcal} / \mathrm{mol}$.

\section{Physical characterization of nanoparticles Encapsulation efficiency (EE; \%)}

Based on Eq. (1), the EE was $92.63 \% \pm 1.30 \%$.

\section{UV analysis and in vitro release study}

Chrysin showed a characteristic peak at $348 \mathrm{~nm}$, as shown in Fig. 2. The in vitro chrysin release profile from CCNPs was assessed in the release medium of PBS, $\mathrm{pH}$ 7.4 at $37^{\circ} \mathrm{C}$ for stability and drug release. The chrysin release over time is shown in Fig. 3. The drug release kinetics of CCNPs showed an initial burst release followed by a steady release after $8 \mathrm{~h}$. The first burst release was observed in the first $2 \mathrm{~h}$ with $28.86 \% \pm 0.057 \%$ chrysin release. The second burst was observed after $8 \mathrm{~h}$, with $68.43 \% \pm 0.015 \%$ chrysin release. The graph forms a plateau from 18 to $24 \mathrm{~h}$. A total of $90 \% \pm 1.039 \%$ chrysin was released from the NPs within $18 \mathrm{~h}$, as shown in Table 1.

\section{FT-IR spectroscopy}

When comparing the functional groups present in CCNPs with those of their bulk counterparts, chrysin had characteristic bands at 520,720 , and $888 \mathrm{~cm}^{-1}$, indicating the $\mathrm{C}-\mathrm{C}, \mathrm{C}-\mathrm{O}$, and $\mathrm{C}-\mathrm{O}-\mathrm{C}$ stretching vibrations. The characteristic peaks at 1533 and $1653 \mathrm{~cm}^{-1}$ depicted the $\mathrm{C}=\mathrm{O}$ group, whereas the band at $3455 \mathrm{~cm}^{-1}$ was due to the stretching vibration of the $\mathrm{OH}$ group. In contrast, chitosan results in distinct bands at $1080 \mathrm{~cm}^{-1}, 1648 \mathrm{~cm}^{-1}$, and $2889 \mathrm{~cm}^{-1}$, which represent the $\mathrm{CH}_{2}$ group, the amide band, and the $\mathrm{C}-\mathrm{H}$ stretching vibration, respectively. CCNP peaks contain characteristic bands of both chrysin (at $535 \mathrm{~cm}^{-1}, 734 \mathrm{~cm}^{-1}, 888 \mathrm{~cm}^{-1}, 1544 \mathrm{~cm}^{-1}$, and 1650 $\mathrm{cm}^{-1}$ ) and chitosan (at $1648 \mathrm{~cm}^{-1}$ and $2391 \mathrm{~cm}^{-1}$ ). Conversely, a slight shift was also observed at $3346 \mathrm{~cm}^{-1}$, signifying the formation of hydrogen bonds between chrysin and the $\mathrm{NH}_{2}$ groups of chitosan, as shown in Fig. 4.

\section{XRD patterns}

The X-ray diffractogram of chrysin showed characteristic peaks at $12^{\circ}, 14.4^{\circ}, 17.23^{\circ}, 20.18^{\circ}, 22.03^{\circ}, 24.64^{\circ}$, and $27.36^{\circ}$ that were crystalline, whereas chitosan and TPP were semi-crystalline. For the XRD pattern of CCNPs, there was a shift in the peaks to $11.2^{\circ}, 32.2^{\circ}$, $19.6^{\circ}, 27.6^{\circ}$, and $31.96^{\circ}$, which were attributed to the interactions of chrysin/chitosan/TPP (Fig. 5).

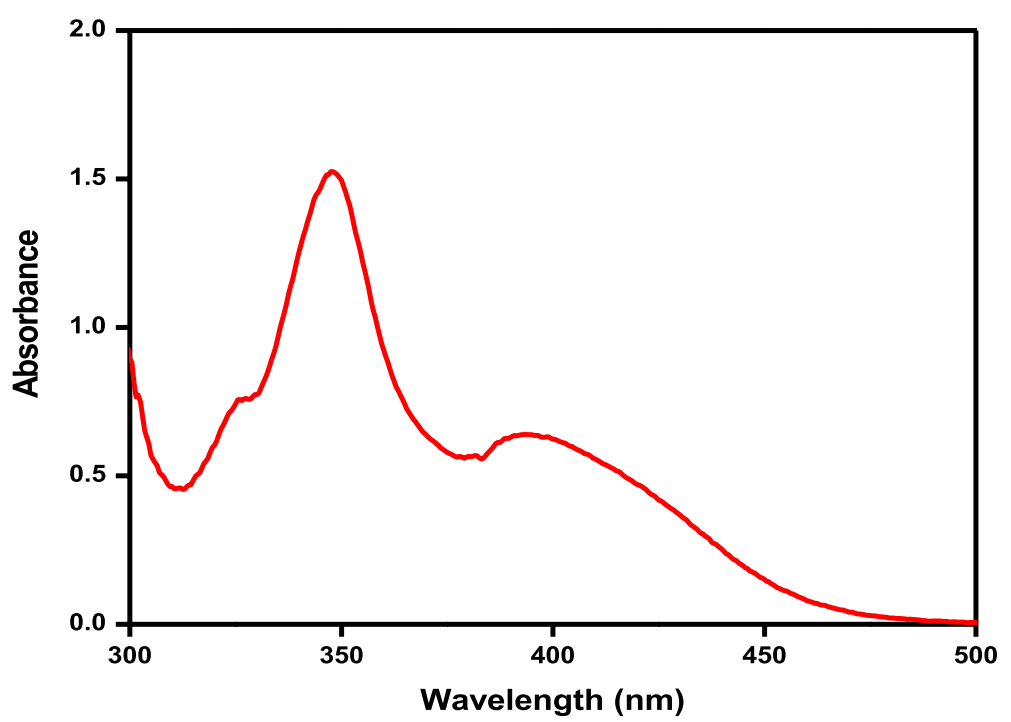

Fig. 2 Ultraviolet absorption spectrum of chrysin 


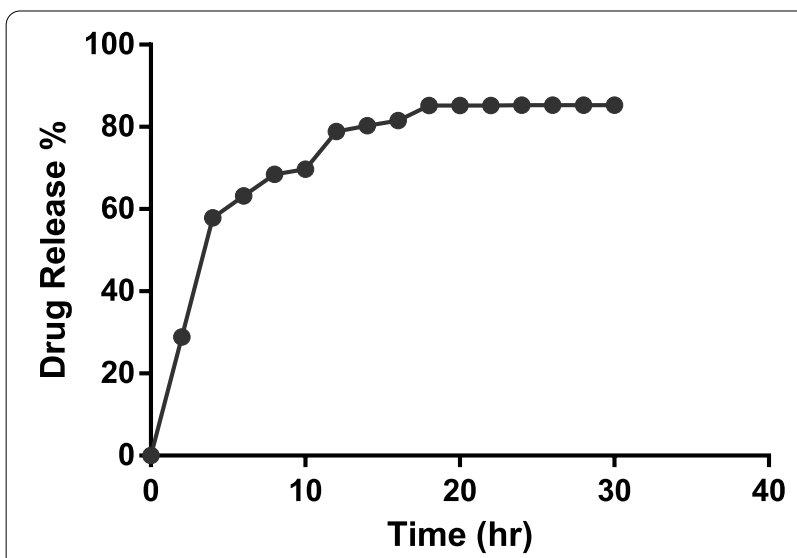

Fig. 3 In vitro drug release profile of chrysin from the CCNPs

\section{Morphology and particle size of nanoparticles}

TEM was used to confirm the particle size and surface morphology of CCNPs, as shown in Fig. 6. The nanoparticles were spherical with an average particle size of 49.7 $\pm 3.02 \mathrm{~nm}$. SEM analysis was used to evaluate the size, surface morphology, and uniformity of chrysin nanoparticles (Fig. 7). The bulk of the biogenic CCNPs showed a more definite structural arrangement; they were spherical with a smooth surface and ranged from 30 to $42 \mathrm{~nm}$ in size. Finally, the dispersion of drug particles was substantially improved.

\section{Zeta potential}

Chitosan nanoparticles generally have a positive zeta potential owing to the cationic properties of the chitosan molecule. Our formulations had a positive zeta potential, of between +35.5 and $+77.02 \mathrm{mV}$ (Fig. 8).

Table 1 The in vitro drug release profile of chrysin from the CCNPS

\begin{tabular}{lll}
\hline NO & Time $(\mathbf{h})$ & Drug release $\%$ \\
\hline 1 & 2 & \\
2 & 4 & $28.86 \pm 0.057$ \\
3 & 6 & $57.88 \pm 0.0057$ \\
4 & 8 & $63.19 \pm 0.0577$ \\
5 & 10 & $68.43 \pm 0.0152$ \\
6 & 12 & $69.70 \pm 0.035$ \\
7 & 14 & $78.9 \pm 0.05$ \\
8 & 16 & $80.28 \pm 0.02$ \\
9 & 18 & $81.55 \pm 0.96$ \\
10 & 20 & $85.2 \pm 1.039$ \\
11 & 22 & $85.2 \pm 1.03$ \\
12 & 24 & $85.2 \pm 1$ \\
\hline
\end{tabular}

Determining $\mathrm{IC}_{50}$ of chrysin, CNPs, CCNPs, and 5-fluorouracil on succinate-ubiquinone oxidoreductase activity (complex II)

The cytotoxic effect of chrysin, CNPs, CCNPs, and 5-fluorouracil was evaluated by the MTT assay (Fig. 9), with $\mathrm{IC}_{50}$ values of $34.66,184.1,12.2$, and $0.05 \mu \mathrm{g} / \mathrm{mL}$ in normal adult mice, and $129,311,156$, and $8.07 \mu \mathrm{g} / \mathrm{mL}$ in normal fibroblasts, respectively (Fig. 10).

Determining succinate dehydrogenase (SDH) and coenzyme $Q$ reductase (complex II) activities by IC $\mathbf{C}_{\mathbf{5 0}}$ The relative SDH activity determined by the MTT test (Table 2) showed that chrysin had more potent inhibitory effects on SDH than on ubiquinone reductase. However, the relative enzyme activity of ubiquinone reductase (Table 2) showed greater targeting of CCNPs to the ubiquinone site compared with chrysin and 5-fluorouracil (Fig. 11A). In normal human fibroblasts, the relative enzyme activity of SDH, as determined by the MTT test (Table 3), showed that chrysin had more potent inhibitory effects on SDH than ubiquinone reductase. However, the relative enzyme activity of ubiquinone reductase (Table 3) showed that CCNPs affected the ubiquinone site than chrysin and 5-fluorouracil (Fig. 11B).

\section{Discussion}

Despite the progress in modern medicine, there are numerous advantages to the use of natural compounds compared with synthetic drugs. Natural compounds have fewer side effects, are nutritionally beneficial, and are less expensive [37]. In accordance with the findings of Hamza et al. [38], chemoprotection, which is based on the use of natural food products, such as ginger, and exogenous phytochemicals to strengthen the endogenous mechanisms against various phases of cancer development, was found to be one of the most effective techniques for minimizing the impact of cancer. Their chemical constituents are believed to have better compatibility with the human body [39]. Bioactive peptides have been shown to influence carcinogenesis-related variables such as oxidative stress and inflammation. As a result, their use in the development of prospective medications, nutraceutical supplements, and other pharmaceutical items has been extensively studied [40]. Natural tablets are frequently preferred because they are less expensive, safer, and have fewer undesirable effects than conventional drugs [41]. Furthermore, a study [42] reported that natural products had enhanced antiproliferative, antidiabetic, and antiinflammatory activities, indicating their potential use as bioactive and functional ingredients. Moreover, the study of $\mathrm{Mu}$ et al. [43] demonstrated that other herbal foodderived active compounds were identified by molecular docking to target the COVID-19 virus. Nanomedicine is 


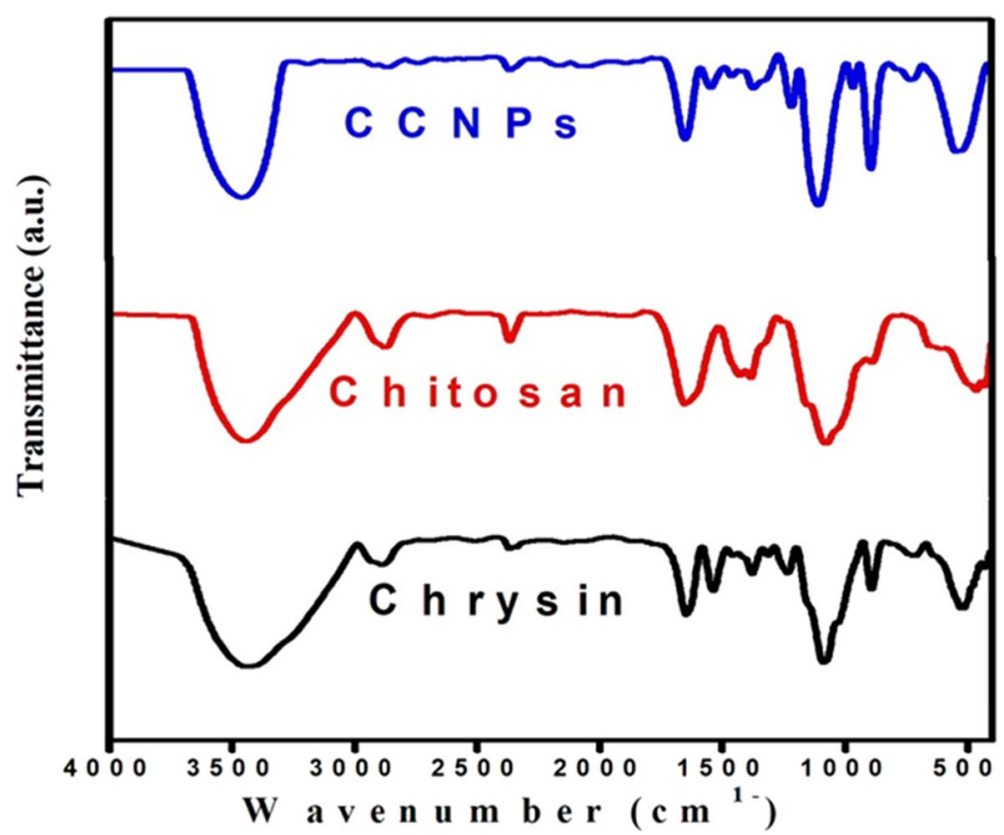

Fig. 4 Fourier transform-infrared (FT-IR) spectroscopy

a major field of nanotechnology that involves the nanotechnological applications utilized for diagnosis, monitoring, biological systems, and therapeutics [10].

The studies outlined in this work indicate targeting that mitochondrial trafficking appears to be a novel therapeutic strategy for this very recalcitrant disease. Respiratory complex II has increasingly been identified as a source and modulator of ROS. In previous studies by Eijkelenkamp et al. [44], it was found that the pharmacological suppression of CII, as well as its functional loss, can

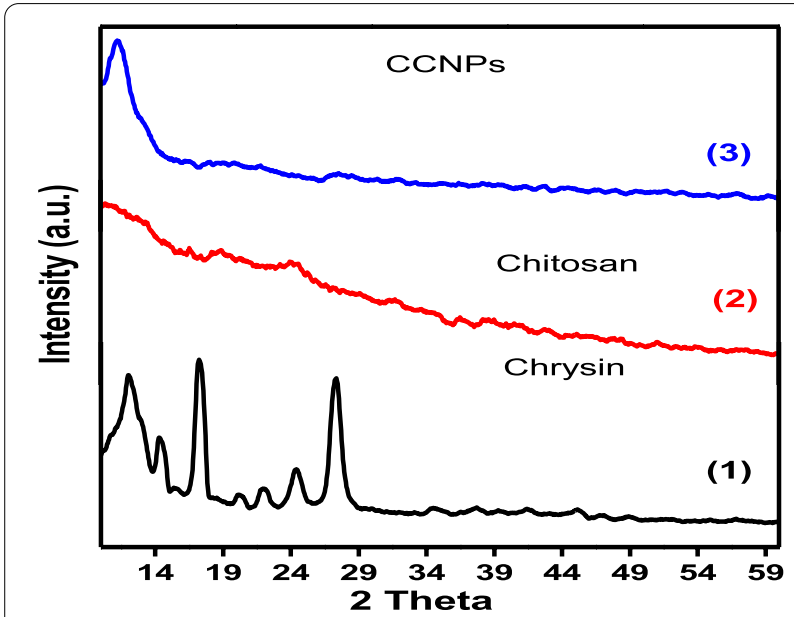

Fig. 5 X-ray diffraction (XRD) pattern of (1) chrysin, (2) chitosan, and (3) CCNPs be used to treat a variety of illnesses, including cancer. Although the basic framework for CII involvement has been established, the finer details are still under investigation. To completely comprehend the role of $\mathrm{CII}$ and to investigate its therapeutic potential in cancer and other disorders, these issues must be resolved. The anticancer activities of several drugs that influence SDH activity have been investigated. One of these molecules is chrysin, an abundant natural flavonoid in beeswax; in recent studies, this molecule has been demonstrated to have many biological functions, including anti-inflammation, anticancer, and antioxidation properties. However, the mechanisms underlying the anticancer effects of chrysin are not well understood. The potential of chrysin as a chemopreventive agent has been demonstrated [45]. However, owing to its poor solubility, it is poorly absorbed in the body. Nano-encapsulation is a most interesting solution to this problem. The bioavailability of chrysin can be improved through the alteration of its pharmacokinetic properties and biodistribution. Nanoparticles made of biodegradable polymer materials, such as chitosan, have been studied as potential drugs, notably in oncology therapy. Chitosan is composed of two subunits of $\mathrm{D}$-glucosamine and $\mathrm{N}$-acetyl-D-glucosamine, which are bound together by a $(1,4)$-glycosidic bond [46] The amine group on the glucosamine unit of chitosan is crucial because it provides a strong and reactive positive charge. The positive charge of chitosan can combine 

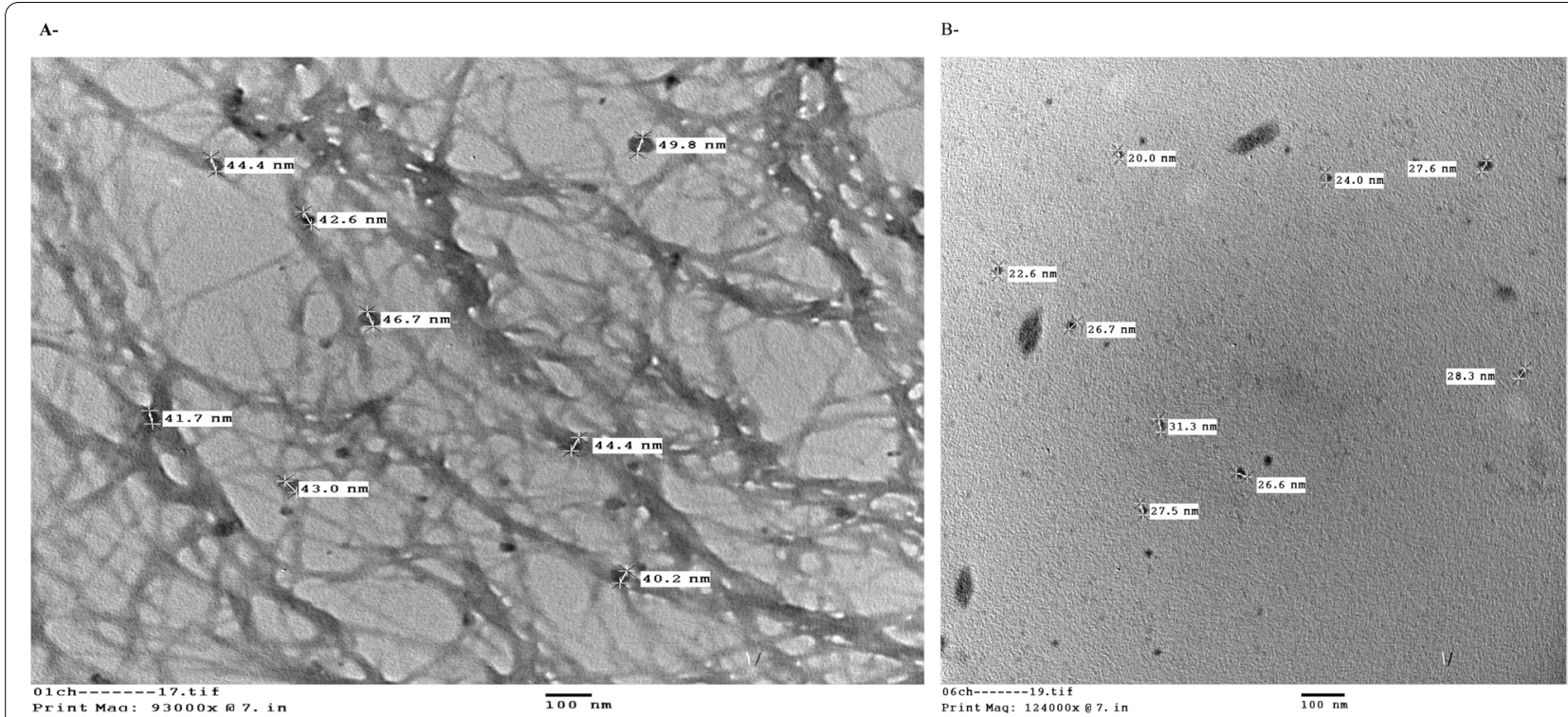

Fig. 6 TEM micrograph showing A chitosan-chrysin nanoparticles (CCNPs) with average size $49.7 \pm 3.02 \mathrm{~nm}$. B Chitosan nanoparticles (CNPs) with average size $26 \pm 3.3 \mathrm{~nm}$

with an anionic molecule to produce a complex. Chitosan can also increase the number of drugs that get through the cell membrane. In our studies, we showed the effect of chrysin and CCNPs on mitochondrial CII subunits activity compared with 5 -fluorouracil from both theoretical and experimental perspectives. Chrysin selected through virtual screening was docked into the active site of the target SDH subunits $\mathrm{A}, \mathrm{B}, \mathrm{C}$, and D, by molecular docking software. Our results showed that the binding energy was $-4.9,-5,-8.2$, and $-8.4 \mathrm{kcal} / \mathrm{mol}$, respectively, which correlated well with the ubiquinone binding of SDH. These results strongly suggested that the SDH C and $\mathrm{D}$ subunits may interact with chrysin by forming a possible conventional hydrogen bond as (VAL 272, VAL 296, ILE 183, ARG 203, ASP 203, ARG 298, THR 250, LEU 274) and C-H (GLY 181, PRO 182, CYS 249) at

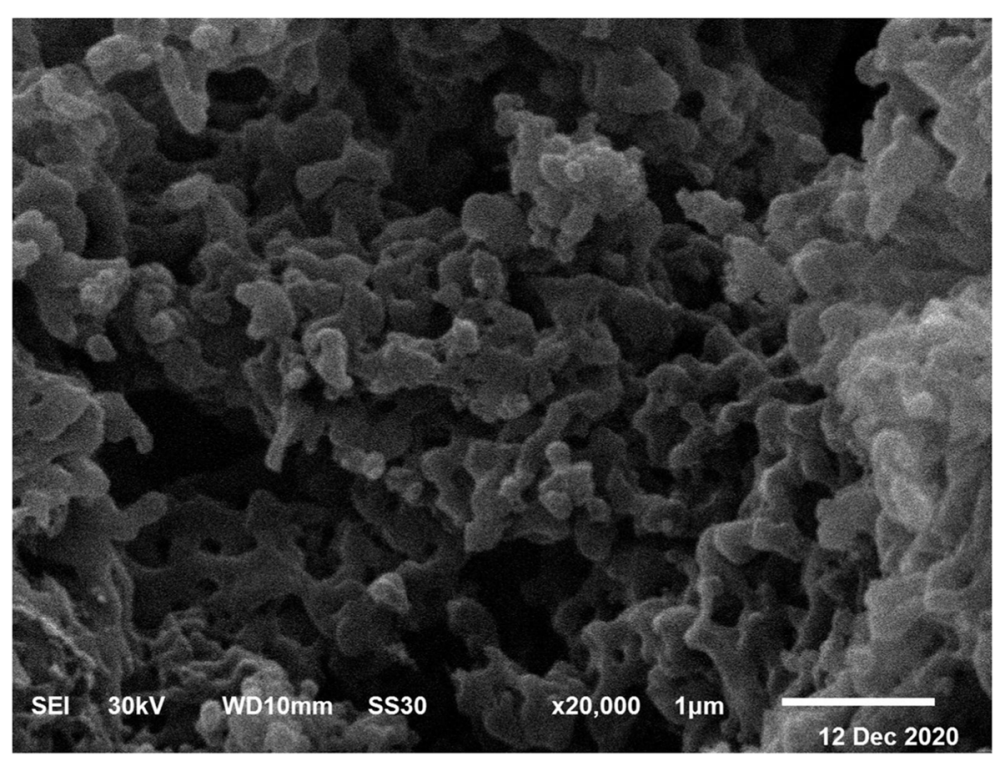

Fig. 7 SEM micrograph showing surface morphology of chitosan-chrysin nanoparticles 


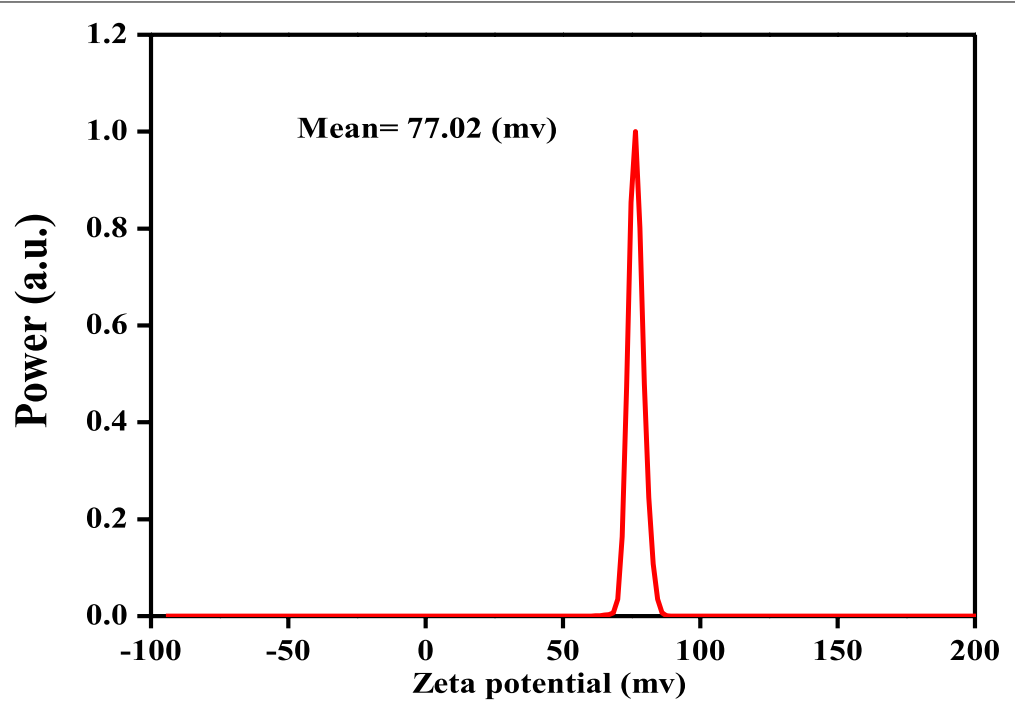

Fig. 8 Zeta potential of chitosan-chrysin nanoparticles
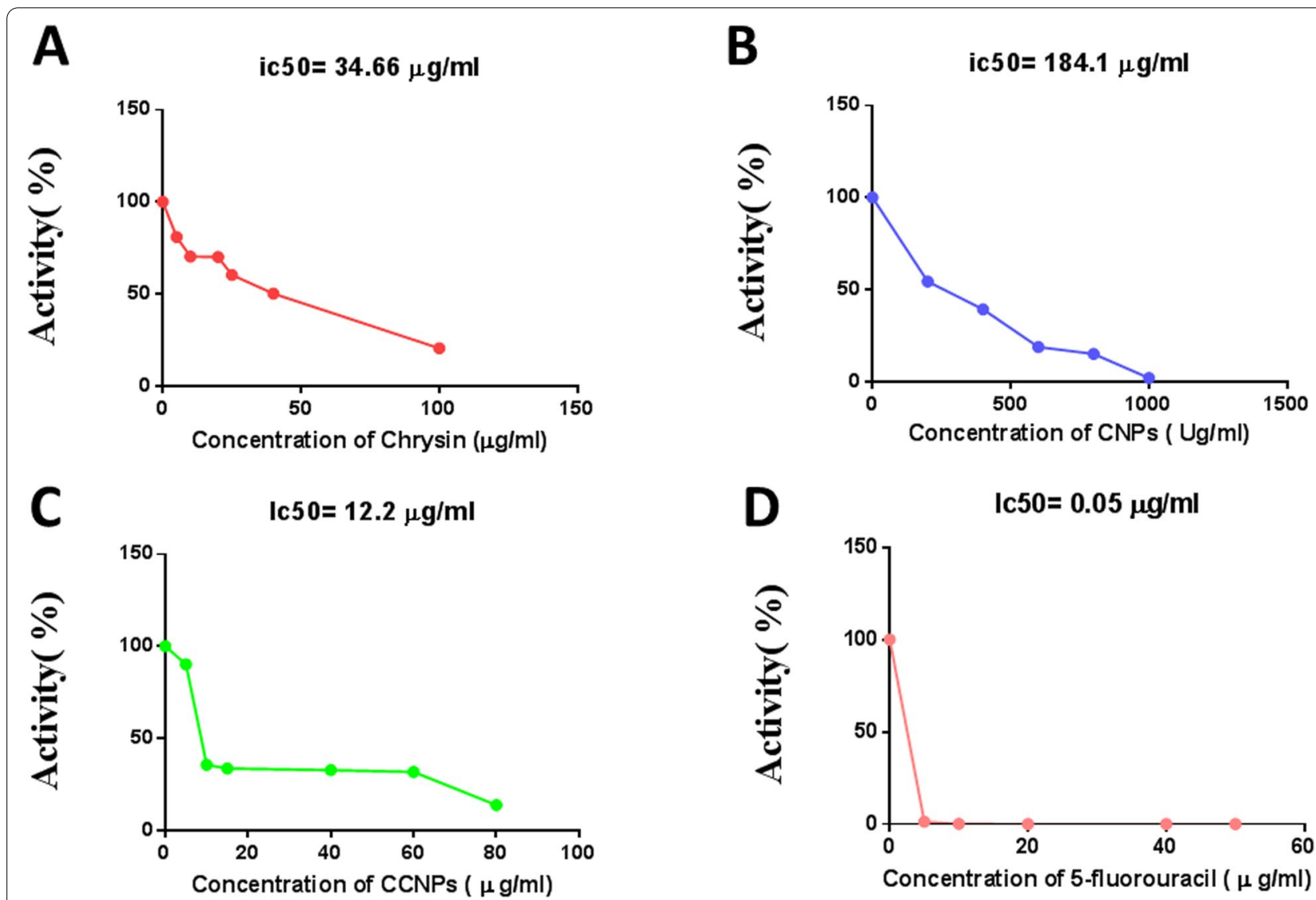

Fig. $9 I_{50}$ of $\mathbf{A}$ chrysin, B chitosan nanoparticles (CNPs), C chrysin-chitosan nanoparticles (CCNPs), and $\mathbf{D}$ 5-fluorouracil of complex II in normal mice liver 

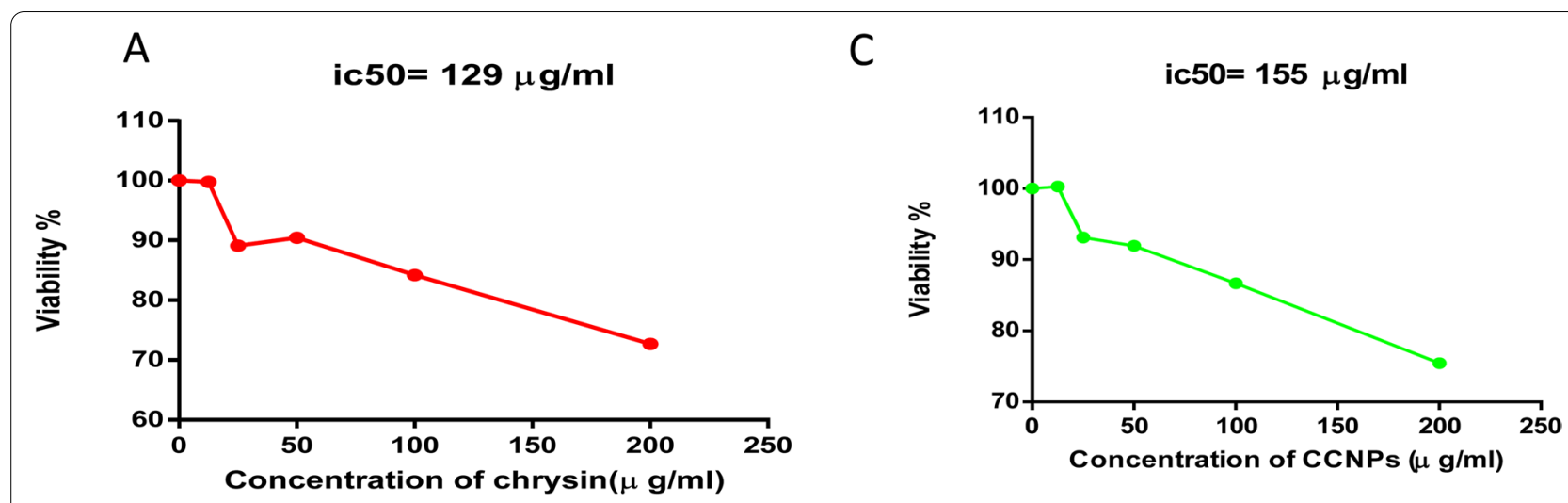

\section{B}

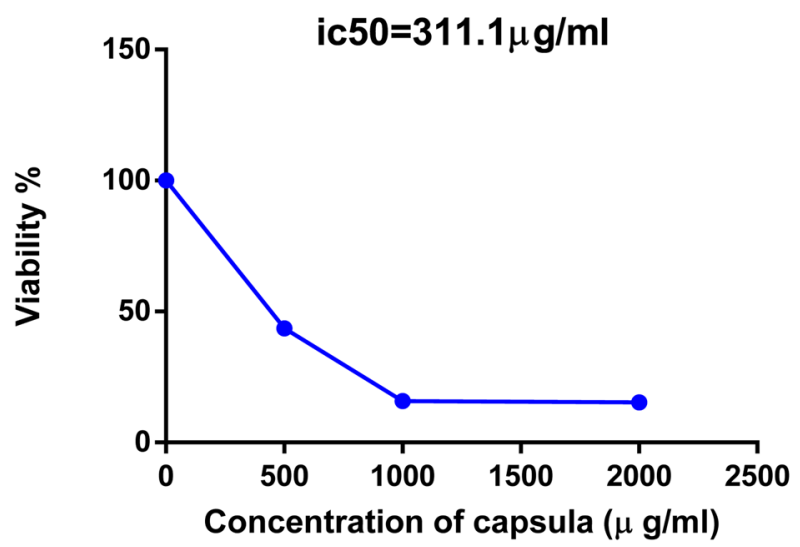

D

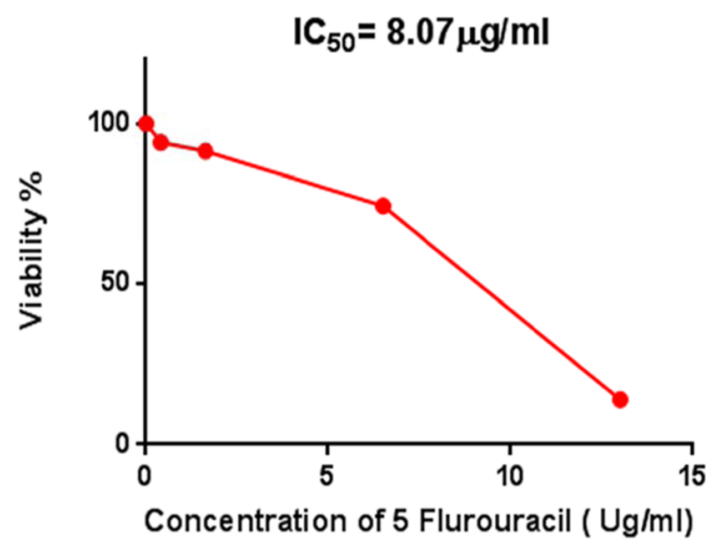

Fig. $10 I C_{50}$ of compounds $\mathbf{A}$ chrysin, $\mathbf{B}$ chitosan nanoparticles (CNPs), $\mathbf{C}$ chrysin-chitosan nanoparticles (CCNPs), and $\mathbf{D}$ 5-fluorouracil of complex II in normal fibroblast cell line

the active site side chain. This correlated better with the ubiquinone binding subunit of SDH than the succinate and iron-sulfur cluster binding subunits [14]. This study employed the technique of ionic gelation in the manufacture of low-weight compounds with good encapsulation efficiency [47]. The physicochemical characterization of CCNPs showed a distinctive peak of UV analysis at 348 $\mathrm{nm}$. The FT-IR analysis showed that the peaks of CCNPs include absorption bands for both chrysin and chitosan. However, a small shift was also noted at $3346 \mathrm{~cm}^{-1}$ for chitosan, resulting from the formation of chrysin and $\mathrm{NH}_{2}$ hydrogen bonds. In the XRD pattern of CCNPs, there was a shift in peaks that was attributed to the interaction between chrysin, chitosan, and TPP. However, the formation of CCNPs resulted in the disappearance of some chitosan peaks and the suppression of other peaks in chrysin. During blending/co-mixing with TPP, the crystalline nature of chrysin was lost, resulting in an amorphous phase. Solid-state amorphization increases compound solubility and bioavailability. Therefore, the semi-crystalline CCNPs provide an optimal structure favoring applications of tissue engineering $[15,18]$.

CCNPs were prepared by ionic crosslinking with TPP at a 5:1 mass ratio. Typically, the surface charge of NPs is a key parameter affecting the short- and longterm stability of NPs. In our study, the surface charge of the particles, as determined by zeta potential, was increased. The increase in surface charge could be due to less neutralization of the $\mathrm{NH}_{3}$ groups by the TPP crosslinker. Particles with a high positive charge are more stable and possess the properties of mucoadhesion and tissue permeation. Chitosan nanoparticles have a positive zeta potential, which improves drug delivery by facilitating attachment to negatively charged cell membranes and increases CCNPs stability [48]. It was observed that as the mass ratio increased, the size of the particle decreased. Consequently, CCNPs can more effectively supply drugs to tissue or cells. The anticancer potency can therefore be increased relative to the use of chrysin alone. The spherical form can 
Table 2 Determination of succinate dehydrogenase (SDH) and coenzyme Q reductase (complex II) activities by $I C_{50}$

\begin{tabular}{|c|c|c|c|c|c|}
\hline Relative enzyme activity \% & $\begin{array}{l}\text { Negative control } \\
\text { (untreated cells) }\end{array}$ & $\begin{array}{l}\text { Chrysin } \\
\text { Mean } \pm \text { SEM } \\
{ }^{*} p \text { value }\end{array}$ & $\begin{array}{l}\text { CNPs } \\
\text { Mean } \pm \text { SEM } \\
{ }^{*} p \text { value }\end{array}$ & $\begin{array}{l}\text { CCNPs } \\
\text { Mean } \pm \text { SEM } \\
{ }^{*} p \text { value }\end{array}$ & $\begin{array}{l}\text { 5-Fluorouracil } \\
\text { Mean } \pm \text { SEM } \\
{ }^{*} p \text { value }\end{array}$ \\
\hline Succinate dehydrogenase by MTT test & $100 \pm 0$ & $\begin{array}{l}40.14 \pm 0.03 \\
P<0.0001\end{array}$ & $\begin{array}{l}90.9 \pm 0.005 \\
P<0.0001\end{array}$ & $\begin{array}{l}86.7 \pm 0.041 \\
P<0.0001\end{array}$ & $\begin{array}{l}89 \pm 0.02 \\
P<0.0001\end{array}$ \\
\hline Ubiquinone reductase by DCPI dye & $100 \pm 0$ & $\begin{array}{l}70.90 \pm 0.003 \\
P<0.0001\end{array}$ & $\begin{array}{l}86.74 \pm 0.005 \\
P<0.0001\end{array}$ & $\begin{array}{l}60.8 \pm 0.002 \\
P<0.0001\end{array}$ & $\begin{array}{l}80.23 \pm 0.02 \\
P<0.0001\end{array}$ \\
\hline
\end{tabular}

${ }^{*} p$ value versus the negative control (untreated cells)

be more easily digested by cells than the rod form of CCNPs [49]. The spherical shape was confirmed by TEM and SEM analyses, but the rough surface of the CCNPs microspheres still contained insoluble particles in the entire matrix owing to the high hydrophobicity of chrysin. Moreover, we hypothesized that the roughness of the surface remained owing to the presence of insoluble drug particles after solvent washing [20,47].

In our studies, we evaluated the $\mathrm{IC}_{50}$ of chrysin, CNPs, CCNPs, and 5-fluorouracil on succinate/ubiquinone oxidoreductase activity (CII) in normal adult mice and normal human fibroblasts. The $\mathrm{IC}_{50}$ of chrysin, CNPs, CCNPs, and 5-fluorouracil was evaluated by MTT assay directly in crude mitochondria with inhibitors of mitochondrial complexes I, III, and IV. The $\mathrm{IC}_{50}$ values were $34.66,184.1,12.2$, and $0.05 \mu \mathrm{g} / \mathrm{mL}$, respectively, in normal adult mice and 129, 311, 156, and $8.07 \mu \mathrm{g} / \mathrm{mL}$, respectively, in normal human fibroblasts. Previous studies have shown that chitosan nanoparticles that encapsulated chrysin have weak cytotoxic effects in normal cells. Based on drug load, the $\mathrm{IC}_{50}$ was significantly lower in CCNPs compared with free chrysin, in addition to the nontoxic effects of CNPs [30]. These results agreed with Seydi et al. [29]. After the $\mathrm{IC}_{50}$ for succinate dehydrogenase (SDH) activity was determined, coenzyme Q reductase (CII) activities were evaluated. The relative enzyme activity of SDH by the MTT test showed that chrysin had more potent inhibitory effects on SDH than ubiquinone reductase. However, the relative enzyme activity of ubiquinone reductase showed that CCNPs were more targeted to the ubiquinone site than chrysin and 5 -fluorouracil, as shown by their relative $\mathrm{IC}_{50}$ values for CII; significant decreases in SDH activity of $40.14 \%$, $90.92 \%, 86.7 \%$, and $89 \%$, and in ubiquinone site activities of $70.90 \%, 86.74 \%, 60.8 \%$, and $80.23 \%$, respectively, in normal adult mice. In contrast, in normal fibroblasts, the activities were $80.90 \%, 89.06 \%$, and $90 \%$ for SDH and $90 \%, 85 \%$, and $95 \%$ for ubiquinone reductase by chrysin, CCNPs, and 5-fluorouracil, respectively. Based on our findings that chrysin significantly decreased the enzyme

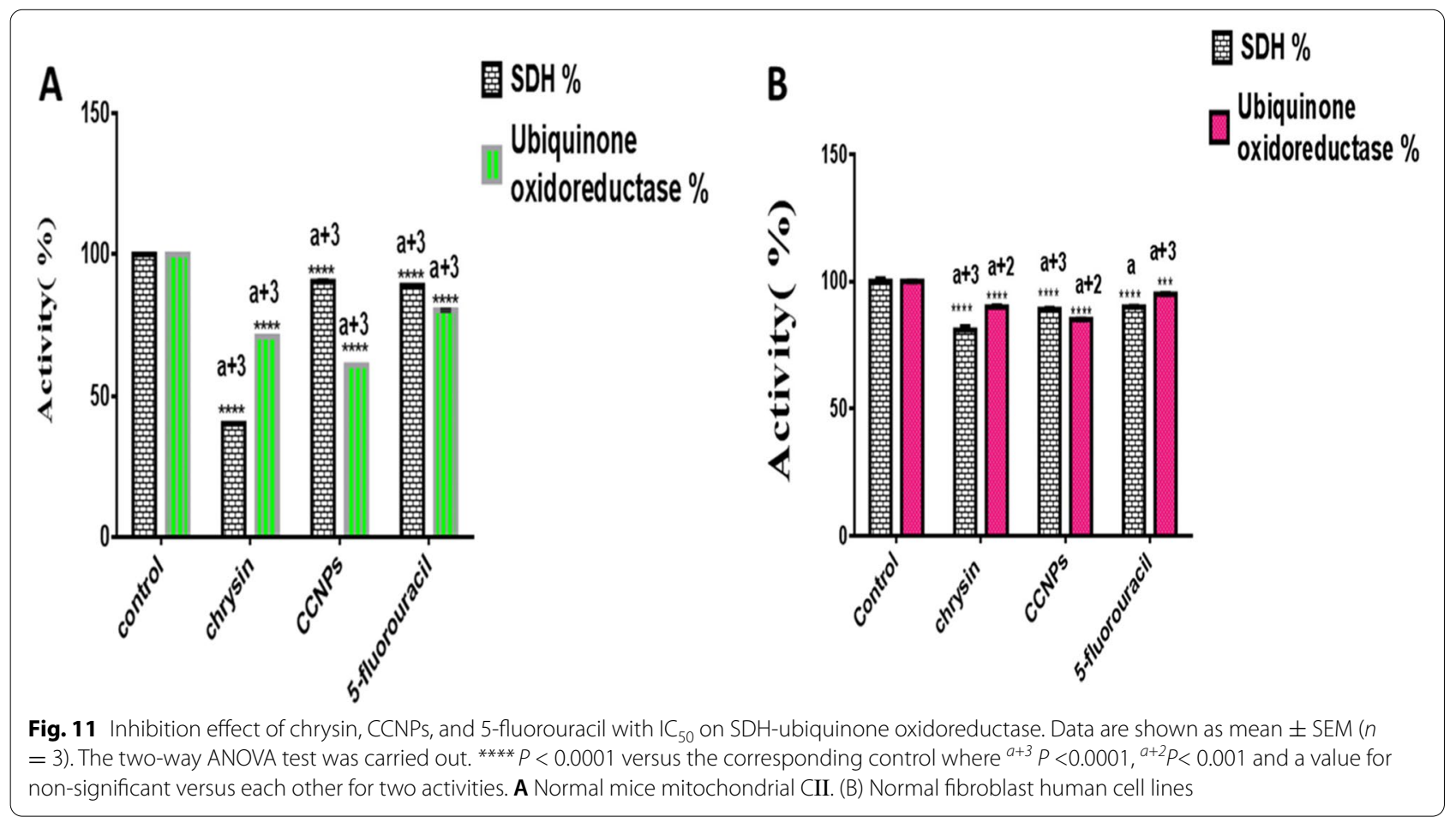


Table 3 Determination of succinate dehydrogenase $(\mathrm{SDH})$ and coenzyme $\mathrm{Q}$ reductase (complex $\mathrm{II}$ ) activities by $\mathrm{IC}_{50}$ in normal fibroblast cell lines

\begin{tabular}{lllll}
\hline Relative enzyme activity \% & $\begin{array}{l}\text { Negative control } \\
\text { (untreated cells) }\end{array}$ & $\begin{array}{l}\text { Chrysin } \\
\text { Mean } \pm \text { SEM } \\
\boldsymbol{*}^{*} \boldsymbol{p} \text {-value }\end{array}$ & $\begin{array}{l}\text { CCNPs } \\
\text { Mean } \pm \text { SEM } \\
\boldsymbol{*}^{p} \boldsymbol{p} \text { value }\end{array}$ & $\begin{array}{l}\text { 5-Fluorouracil } \\
\text { Mean } \pm \text { SEM } \\
\boldsymbol{*}^{*} \boldsymbol{p} \text { value }\end{array}$ \\
\hline Succinate dehydrogenase by MTT test & $100 \pm 0$ & $\begin{array}{l}80.90 \pm 0.003 \\
P<0.0001\end{array}$ & $\begin{array}{l}89.06 \pm 0.0003 \\
P<0.0001\end{array}$ & $\begin{array}{l}90 \pm 0.003 \\
P<0.0001\end{array}$ \\
Ubiquinone reductase by DCPI dye & $100 \pm 0$ & $90 \pm 0.002$ & $\begin{array}{l}85 \pm 0.02 \\
P<0.0001\end{array}$ & $\begin{array}{l}95 \pm 0.001 \\
P<0.0001\end{array}$ \\
\hline
\end{tabular}

${ }^{*} p$ value versus the negative control (untreated cells)

activity of SDH more than CCNPs, and CCNPs reduced ubiquinone oxidoreductase after treatment with the $\mathrm{IC}_{50}$, we proposed that CCNPs displayed better targeting than chrysin. Therefore, we recommend that in silico, in vitro, and in vivo studies of the inhibitory effect on mitochondria CII in most common types of cancer throughout the world should be performed.

\section{Conclusions}

Our study showed that chrysin and CCNPs were more potent inhibitors of the SDH and ubiquinone oxidoreductase activities of CII, respectively. This has previously been proven theoretically using molecular docking, revealing the high binding affinity of chrysin for succinateubiquinone oxidoreductase. Further, we determined the $\mathrm{IC}_{50}$ values of chrysin, CNPs, CCNPs, and 5-fluorouracil against mitochondrial $\mathrm{CII}$ in crude mitochondria isolated from normal mouse liver using the MTT assays and in normal fibroblast cell lines. Overall, we assayed the activity of succinate-ubiquinone oxidoreductase to confirm the previous theory and reveal the mechanisms. Our results showed that chrysin significantly decreased the enzyme activity of SDH more than CCNPs, and that CCNPs reduced ubiquinone oxidoreductase following treatment at the $\mathrm{IC}_{50}$. Based on these inhibitory effects, we predict that chrysin and CCNPs could be considered to have therapeutic effects on mitochondrial CII in cancer cells owing to their inhibition of mitochondrial CII and ROS generation and the induction of apoptosis with the suppression of ATP generation in cancer cells. We investigated the potential anticancer effect of chrysin with respect to clinical application and the recommended evidence. We used molecular docking to provide mechanical insights into potential mechanisms of druggability.

\section{Abbreviations}

SDH: Succinate dehydrogenase; Chr: Chrysin; CCNPs: Chrysin-chitosan nanoparticles; TEM: Transmission electron microscopy; SEM: Scanning electron microscopy; CS: Chitosan; XRD: X-ray diffraction; ETC: Electron transport chain; OXPHOS: Oxidative phosphorylation; TPP: Trisodium Penta polyphosphate; UV: Ultraviolet; EE: Encapsulation efficiency; FTIR: Fourier transform infrared spectroscopy; UE: Electrophoretic mobility; MTT: [3-(4,5-Dimethylthiazol2-yl)-2,5-diphenyltetrazolium bromide]; DMEM: Dulbecco's modified Eagle's medium; FBS: Fetal bovine serum; PDB: Protein Data Bank.

\section{Supplementary Information}

The online version contains supplementary material available at https://doi. org/10.1186/s43141-021-00286-0.

Additional file 1:The ARRIVE Essential 10: Compliance Questionnaire.

\section{Acknowledgements}

Thanks to the Chemistry department, Faculty of Science, and Faculty of Medicine, Tanta University, where all analyses and experiments were carried out.

\section{Authors' contributions}

RE: methodology and writing — original draft preparation. GD: supervision and investigation. MT: conceptualization and formal analysis. KA: reviewing and editing. The authors read and approved the final manuscript.

Funding

Not applicable.

Availability of data and materials

Not applicable.

\section{Declarations}

Ethics approval and consent to participate

The experiments on experimental animals will be monitored by the Egyptian Ethical Committee of Tanta University's Faculty of Science (IACUC-SCI-TU-0165).

\section{Consent for publication}

Not applicable.

\section{Competing interests}

The authors declare that they have no competing interests.

Received: 16 September 2021 Accepted: 13 December 2021

Published online: 28 January 2022

\section{References}

1. Jones AE, Sheng L, Acevedo A, Veliova M, Shirihai OS, Stiles L, Divakaruni AS (2021) Forces, fluxes, and fuels: tracking mitochondrial metabolism by integrating measurements of membrane potential, respiration, and metabolites. Am J Physiol Cell Physiol. 320(1):C80-C91. https://doi.org/10. 1152/ajpcell.00235.2020

2. Boreel DF, Span PN, Heskamp S, Adema GJ, Bussink J (2021) Targeting oxidative phosphorylation to increase the efficacy of radio-and immunecombination therapy. Clin Cancer Res 27(11):2970-2978. https://doi.org/ 10.1158/1078-0432.CCR-20-3913 
3. Maclean AE, Bridges HR, Silva MF, Ding S, Ovciarikova J, Hirst J, Sheiner L (2021) Complexome profile of Toxoplasma gondii mitochondria identifies divergent subunits of respiratory chain complexes including new subunits of cytochrome bc 1 complex. PLoS Pathog. 17(3):e1009301. https:// doi.org/10.1371/journal.ppat.1009301

4. Park H, Lee JY, Lim W, Song G (2021) Assessment of the in vivo genotoxicity of pendimethalin via mitochondrial bioenergetics and transcriptional profiles during embryogenesis in zebrafish: Implication of electron transport chain activity and developmental defects. J Hazard Mater 411:125153. https://doi.org/10.1016/j.jhazmat.2021.125153

5. Wong HS, Mezera V, Dighe P, Melov S, Gerencser AA, Sweis RF, Pliushchev M, Wang Z, Esbenshade T, McKibben B, Riedmaier S, Brand MD (2021) Superoxide produced by mitochondrial site IQ inactivates cardiac succinate dehydrogenase and induces hepatic steatosis in Sod2 knockout mice. Free Radic Biol Med 164:223-232. https://doi.org/10.1016/j.freer adbiomed.2020.12.447

6. Matlac DM, Hadrava Vanova K, Bechmann N, Richter S, Folberth J, Ghayee HK, Ge GB, Abunimer L, Wesley R, Aherrahrou R, Dona M, MartínezMontes ÁM, Calsina B, Merino MJ, Schwaninger M, Deen P, Zhuang Z, Neuzil J, Pacak K, Lehnert H, Fliedner S (2021) Succinate mediates tumorigenic effects via succinate receptor 1: potential for new targeted treatment strategies in succinate dehydrogenase deficient paragangliomas. Front Endocrinol 12:589451. https://doi.org/10.3389/fendo.2021. 589451

7. Juaid N, Amin A, Abdalla A, Reese K, Alamri Z, Moulay M, AbduS MN (2021) Anti-hepatocellular carcinoma biomolecules: molecular targets insights. Int J Mol Sci 22(19):10774. https://doi.org/10.3390/ijms221910 774

8. Lee S, Lee SK, Jung J (2021) Potentiating activities of chrysin in the therapeutic efficacy of 5-fluorouracil in gastric cancer cells. Oncol Lett 21(1):24. https://doi.org/10.3892/ol.2020.12285

9. Azar LK, Dadashpour M, Firouzi-Amandi A, Zarghami N (2021) Design and development of nanostructured co delivery of artemisinin and chrysin for targeting hTERT gene expression in breast cancer cell line: possible clinical application in cancer treatment. Res Sq. https://doi.org/10.21203/ rs.3.rs-623122/v1

10. Baig B, Hilal-Alnaqbi A, Amin A (2017) Cancer and biotechnology: a matchup that should never slowdown. In: Biotechnology and Production of Anti-Cancer Compounds. Springer, Cham, pp 73-97. https://doi.org/ 10.1007/978-3-319-53880-8_3

11. Parolia A, Kumar H, Ramamurthy S, Madheswaran T, Davamani F, Pichika MR, Mak KK, Fawzy AS, Daood U, Pau A (2021) Effect of propolis nanoparticles against Enterococcus faecalis biofilm in the root canal. Molecules (Basel, Switzerland) 26(3):715. https://doi.org/10.3390/molecules26030715

12. Kaparekar PS, Poddar N, Anandasadagopan SK (2021) Fabrication and characterization of Chrysin-a plant polyphenol loaded alginate-chitosan composite for wound healing application. Colloids Surf B 206:111922 Advance online publication. https://doi.org/10.1016/j.colsurfb.2021. 111922

13. Muhammad I, Rahman N, Nayab GE, Niaz S, Shah M, Afridi SG, Khan H, Daglia M, Capanoglu E (2020) The molecular docking of flavonoids isolated from Daucus carota as a dual inhibitor of MDM2 and MDMX. Recent Pat Anticancer Drug Discov 15(2):154-164. https://doi.org/10.2174/15748 92815666200226112506

14. El-Ghamry H, El-Wakiel N, Khamis A (2018) Synthesis, structure, antiproliferative activity and molecular docking of divalent and trivalent metal complexes of 4H-3, 5-diamino-1, 2, 4-triazole and a-hydroxynaphthaldehyde Schiff base ligand. Appl Organomet Chem. 32(12):e4583. https://doi.org/10.1002/aoc.4583

15. Siddhardha B, Pandey U, Kaviyarasu K, Pala R, Syed A, Bahkali AH, Elgorban AM (2020) Chrysin-loaded chitosan nanoparticles potentiates antibiofilm activity against Staphylococcus aureus. Pathogens (Basel, Switzerland) 9(2):115. https://doi.org/10.3390/pathogens9020115

16. Kumar SP, Birundha K, Kaveri K, Devi KT (2015) Antioxidant studies of chitosan nanoparticles containing naringenin and their cytotoxicity effects in lung cancer cells. Int J Biol Macromol 78:87-95. https://doi.org/ 10.1016/j.jijbiomac.2015.03.045

17. Khaledi S, Jafari S, Hamidi S, Molavi O, Davaran S (2020) Preparation and characterization of PLGA-PEG-PLGA polymeric nanoparticles for co-delivery of 5-Fluorouracil and Chrysin. J Biomater Sci Polym Ed 31(9):1107-1126. https://doi.org/10.1080/09205063.2020.1743946
18. Menon AH, Soundarya SP, Sanjay V, Chandran SV, Balagangadharan K, Selvamurugan N (2018) Sustained release of chrysin from chitosan-based scaffolds promotes mesenchymal stem cell proliferation and osteoblast differentiation. Carbohydr Polym 195:356-367. https://doi.org/10.1016/j. carbpol.2018.04.115

19. Saleem S (2020) Chitosan nanoparticles alleviate Alzheimer's disease in zebrafish by adopting a dual strategy: Nonhuman/Lead optimization studies. Alzheimers Dement 16:e037238. https://doi.org/10.1002/alz.037238

20. Cho AR, Chun YG, Kim BK, Park DJ (2014) Preparation of chitosan-TPP microspheres as resveratrol carriers. J Food Sci 79(4):E568-E576. https:// doi.org/10.1111/1750-3841.12395

21. Ghamkhari A, Pouyafar A, Salehi R, Rahbarghazi R (2019) Chrysin and docetaxel loaded biodegradable micelle for combination chemotherapy of cancer stem cell. Pharm Res. 36(12):165. https://doi.org/10.1007/ s1 1095-019-2694-4

22. Zhang Y, Zhao J, Afzal O, Kazmi I, Al-Abbasi FA, Altamimi A, Yang Z (2021) Neuroprotective role of chrysin-loaded poly (lactic-co-glycolic acid) nanoparticle against kindling-induced epilepsy through Nrf2/ARE/HO-1 pathway. J Biochem Mol 35(2):e22634. https://doi.org/10.1002/jbt.22634

23. Lotfi-Attari J, Pilehvar-Soltanahmadi Y, Dadashpour M, Alipour S, Farajzadeh R, Javidfar S, Zarghami N (2017) Co-delivery of curcumin and chrysin by polymeric nanoparticles inhibit synergistically growth and hTERT gene expression in human colorectal cancer cells. Nutr Cancer 69(8):12901299 https://doi.org/10.1080/01635581.2017.1367932

24. Alqahtani F, Aleanizy F, El Tahir E, Alhabib H, Alsaif R, Shazly G, AlQahtani H, Alsarra I, Mahdavi J (2020) Antibacterial activity of chitosan nanoparticles against pathogenic N. gonorrhoea. Int J Nanomed 15:7877-7887. https://doi.org/10.2147/IJN.S272736

25. Sert NP, Bamsey I, Bate ST, Berdoy M, Clark RA, Cuthill I, Fry D, Karp NA, Macleod M, Moon L, Stanford SC (2017) The experimental design assistant. PLoS Biol 15(9):1-9. https://doi.org/10.1371/journal.pbio.2003779

26. Albasher G, Alwahaibi M, Abdel-Daim MM, Alkahtani S, Almeer R (2020) Protective effects of Artemisia judaica extract compared to metformin against hepatorenal injury in high-fat diet/streptozotocine-induced diabetic rats. Environ Sci Pollut Res 27(32):40525-40536. https://doi.org/ 10.1007/s11356-020-09997-2

27. Frezza C, Cipolat S, Scorrano L (2007) Organelle isolation: functional mitochondria from mouse liver, muscle and cultured filroblasts. Nat Protoc 2(2):287-295. https://doi.org/10.1038/nprot.2006.478

28. Mignard V, Dubois N, Lanoé D, Joalland MP, Oliver L, Pecqueur C, Lalier L (2020) Sphingolipid distribution at mitochondria-associated membranes (MAMs) upon induction of apoptosis [S]. J Lipid Res 61(7):1025-1037. https://doi.org/10.1194/jlr.RA120000628

29. Seydi E, Rahimpour Z, Salimi A, Pourahmad J (2019) Selective toxicity of chrysin on mitochondria isolated from liver of a HCC rat model. Bioorg Med Chem 27(24):115163. https://doi.org/10.1016/j.bmc.2019.115163

30. Jones CG, Daniel Hare J, Compton SJ (1989) Measuring plant protein with the Bradford assay: 1. Evaluation and standard method. J Chem Ecole 15(3):979-992. https://doi.org/10.1007/BF01015193

31. Taylor RW, Birch-Machin MA, Bartlett K, Lowerson SA, Turnbull DM (1994) The control of mitochondrial oxidations by complex III in rat muscle and liver mitochondria. Implications for our understanding of mitochondrial cytopathies in man. Int J Biol Chem 269(5):3523-3528. https://doi.org/10. 1016/50021-9258(17)41894-1

32. Mohamed TM, Youssef M, Bakry AA, El-Keiy MM (2021) Alzheimer's disease improved through the activity of mitochondrial chain complexes and their gene expression in rats by boswellic acid. Metab Brain Dis 36(2):255-264. https://doi.org/10.1007/s11011-020-00639-7

33. Northrop RB (2014) Introduction to complexity and complex systems. CRC press. https://doi.org/10.1201/9781439894989

34. Denizot F, Lang R (1986) Rapid colorimetric assay for cell growth and survival: modifications to the tetrazolium dye procedure giving improved sensitivity and reliability. J Immunol Method 89(2):271-277. https://doi. org/10.1016/0022-1759(86)90368-6

35. Park JG, Ku JL, Park SY (2004) Isolation and culture of colon cancer cell lines. In: Langdon SP (ed) Cancer Cell Culture. Methods in Molecular Medicine ${ }^{\mathrm{TM}}$, vol 88. Humana Press https://doi.org/10.1385/1-59259-406-9:79

36. Wieckowski MR, Giorgi C, Lebiedzinska M, Duszynski J, Pinton P (2009) Isolation of mitochondria-associated membranes and mitochondria from animal tissues and cells. Nat Protoc 4(11):1582-1590. https://doi.org/10. 1038/nprot.2009.151 
37. Amin A, Farrukh A, Murali C, Soleimani A, Praz F, Graziani G, Brim H, Ashktorab H (2021) Saffron and its major ingredients' effect on colon cancer cells with mismatch repair deficiency and microsatellite instability. Molecules. 26(13):3855. https://doi.org/10.3390/molecules26133855

38. Hamza AA, Heeba GH, Hamza S, Abdalla A, Amin A (2021) Standardized extract of ginger ameliorates liver cancer by reducing proliferation and inducing apoptosis through inhibition oxidative stress/inflammation pathway. Biomed Pharmacother. 134:111102. https://doi.org/10.1016/j. biopha.2020.111102

39. Ashktorab H, Soleimani A, Singh G, Amin A, Tabtabaei S, Latella G, Stein U, Akhondzadeh S, Solanki N, Gondré-Lewis MC, Habtezion A, Brim H (2019) Saffron: the golden spice with therapeutic properties on digestive diseases. Nutrients 11(5):943. https://doi.org/10.3390/nu11050943

40. Murali C, Mudgil P, Gan CY, Tarazi H, El-Awady R, Abdalla Y, Amin A, Maqsood S (2021) Camel whey protein hydrolysates induced G2/M cellcycle arrest in human colorectal carcinoma. Sci Rep 11(1):7062. https:// doi.org/10.1038/s41598-021-86391-z

41. Hamza AA, Lashin FM, Gamel M, Hassanin SO, Abdalla Y, Amin A (2020) Hawthorn herbal preparation from Crataegus oxyacantha attenuates in vivo carbon tetrachloride-induced hepatic fibrosis via modulating oxidative stress and inflammation. Antioxidants. 9(12):1173. https://doi. org/10.3390/antiox9121173

42. Kamal H, Jafar S, Mudgil P, Murali C, Amin A, Maqsood S (2018) Inhibitory properties of camel whey protein hydrolysates toward liver cancer cells, dipeptidyl peptidase-IV, and inflammation. J Dairy Sci. 101(10):87118720. https://doi.org/10.3168/jds.2018-14586

43. Mu C, Sheng Y, Wang Q, Amin A, Li X, Xie Y (2021) Potential compound from herbal food of Rhizoma Polygonati for treatment of COVID-19 analyzed by network pharmacology: Viral and cancer signaling mechanisms. J Funct Foods 77:104149. https://doi.org/10.1016/j.jff.2020.104149

44. Eijkelenkamp K, Osinga TE, Links TP, van der Horst-SChrivers A (2020) Clinical implications of the oncometabolite succinate in SDHx-mutation carriers. Clin Genet 97(1):39-53. https://doi.org/10.1111/cge.13553

45. Dalla Pozza E, Dando I, Pacchiana R, Liboi E, Scupoli MT, Donadelli M, Palmieri M (2020) Regulation of succinate dehydrogenase and role of succinate in cancer. Semin Cell Dev Biol 98:4-14 https://doi.org/10.1016/j. semcdb.2019.04.013

46. Pedroso-Santana S (2020) Fleitas-Salazar N (2020) Ionotropic gelation method in the synthesis of nanoparticles/microparticles for biomedical purposes. Polym Int 69(5):443-447. https://doi.org/10.1002/pi.5970

47. Villegas-Peralta Y, López-Cervantes J, Santana TJM, Sánchez-Duarte RG, Sánchez-Machado Dl, del Rosario Martínez-Macías M, Correa-Murrieta MA (2021) Impact of the molecular weight on the size of chitosan nanoparticles: characterization and its solid-state application. Polym Bull 78(2):813-832. https://doi.org/10.1007/s00289-020-03139-x

48. Ong TH, Chitra E, Ramamurthy S, Siddalingam RP, Yuen KH, Ambu SP, Davamani F (2017) Chitosan-propolis nanoparticle formulation demonstrates anti-bacterial activity against Enterococcus faecalis biofilms. PLoS One 12(3):e0174888. https://doi.org/10.1371/journal.pone.0174888

49. Akrawi SH, Gorain B, Nair AB, Choudhury H, Pandey M, Shah JN, Venugopala KN (2020) Development and optimization of naringenin-loaded chitosan-coated nanoemulsion for topical therapy in wound healing. Pharmaceutics 12(9):893. https://doi.org/10.3390/pharmaceutics 12 090893

\section{Publisher's Note}

Springer Nature remains neutral with regard to jurisdictional claims in published maps and institutional affiliations.

\section{Submit your manuscript to a SpringerOpen ${ }^{\circ}$ journal and benefit from:}

- Convenient online submission

- Rigorous peer review

- Open access: articles freely available online

- High visibility within the field

- Retaining the copyright to your article

Submit your next manuscript at $\boldsymbol{\nabla}$ springeropen.com 